\title{
PENDIDIKAN MODERASI BERAGAMA \\ PESERTA DIDIK MADRASAH ALIYAH \\ MUHAMMADIYAH ISIMU KABUPATEN \\ GORONTALO
}

\section{Hj. Mujizatullah*}

Balai Peneitian dan Pengembangan Agama Makassar Jl. AP.Pettarani No.72 Makassar. Email: mujizatullah_67@gmail.com INFO ARTIKEL

ABSTRAK

Penelitian ini bertujuan untuk mengetahui moderasi beragama para peserta didik. pada Madrasah Aliyah Swasta Muhammadiyah Isimu Kabupaten Gorontalo. Penelitian ini menggunakan metode kualitatif. Tekhnik pengumpulan data dengan wawancara pada beberapa informan diantaranya kepala madrasah aliyah, Guru Pendidikan agama, Siswa selanjutnya mengamati langsung kegiatan proses pembelajaran. Penelitian ini menghasilakan suatu kesimpulan bahwa madrasah yang terdiri dari ragam mazhab dan etnis tersebut memperoleh pendidikan nilainilai moderasi beragama melalui kegiatan pembelajaran intrakurikuler dengan tekhnik pembelajaran di integrasikan pada mata pelajaran agama dan kegiatan

\section{Kata Kunci: \\ moderasi beragama, \\ Peserta didik, \\ Madrasah Aliyah, \\ Muhammadiyah.} ekstrakurikuler (kegiatan Rohis) dan mampu mengimplementasikan sikap toleransi dan akomodatif terhadap budaya lokal dengan cukup baik. Siswa yang selama ini dipersepsi intoleran dan tidak akomodatif dengan budaya lokal, tidak terjadi di madrasah ini. Bahkan nilai-nilai moderasi beragama yang terintegrasi dalam pelajaran muatan lokal yakni kemuhammadiyahan telah diimplementasikan di lingkungan madrasah.

\section{ABSTRACT}

This study aims to determine the religious moderation of students. at the Muhammadiyah Aliyah Private Madrasah Isimu Gorontalo District. This study uses a qualitative method. Data collection techniques by interviewing several informants including the headmaster of madrasas aliyah, religious education teachers, students then observe directly the learning process activities. This research resulted in a conclusion that the madrasa consisting of various schools and ethnicities received the education of religious moderation values through intracuricular learning activities with learning techniques integrated into religious subjects and extracurricular activities (Rohis activities) and able to implement tolerance and accommodative attitudes towards local culture quite well. Students who have been perceived intolerant and are not accommodating with local culture, do not occur in this madrasa. Even the values of religious moderation integrated in local content lessons namely kemuhammadiyahan have been implemented in the madrasa environment

\section{PENDAHULUAN}

Moderasi beragama ditanamkan pada siswa supaya siswa mempunyai pemahaman yang luas mengenai keragaman dan serta moderasi beragama dan berperspektif damai adalah jaminan untuk kedamaian sosial.

Upaya memberikan pemahaman Moderasi Beragama merupakan langkah strategis dalam mengkounter isu yang pernah menyebar dalam masyarakat bahwa peserta didik di Madrasah banyak mengarah pada pemikiran radikalisme dalam memahami ajaran agama. Bahkan ini saatnya membentuk pemahaman moderasi beragama secara utuh dan komprehensif berdasarkan Keputusan Presiden Nomor 22 Tahun

Sasaran moderasi beragama dalam hal paham moderasi beragama bagi peserta didik di madrasah sangat penting disebabkan pengaruh komunitas radikal dan 
intoleran sehingga di perlukan pemahaman moderasi beragama

Guru agama, ulama dan kiai sangat besar peranannya dalam menanamkan pemahaman moderasi beragama. Pendidikan agama harus dapat memperkuat ide-ide pemikiran-pemikiran siswa yang sangat relevan untuk mendukung NKRI, Pancasila dan UUD 1945.

Hasil riset Balai Litbang Agama Makassar Tahun 2016 tentang respons siswa terhadap radikalisme agama menunjukkan bahwa mayoritas siswa SMA memiliki nalar keagamaan moderat tetapi data juga menunjukkan bahwa ada 10\% siswa yang setuju dengan tindakan radikalisme agama seperti bom bunuh diri dan tindakan penyerangan terhadap bangunan rumah ibadah. Bahkan, 60\% siswa muslim mengatakan bahwa mengucapkan selamat natal hukumnya haram. Maka perlu dilaksanakan penelitian faham moderasi beragama di madrasah Aliyah.

\section{Rumusan Masalah}

Permasalahan nya adalah Bagaimana pemahaman moderasi beragama peserta didik di Madrasah Aliyah Muhammadiyah Isimu Kabupaten Gorontalo yang di hubungkan dengan dengan toleransi dan akomodatif terhadap budaya lokal.

\section{Tujuan dan Kegunaan}

Penelitian ini bertujuan untuk memahami dan di implementasikan serta harapan peserta didik di Madrasah Aliyah Muhammadiyah Isimu Kabupaten Gorontalo di Provinsi Gorontalo yang dihubungkan dengan toleransi dan akomodatif terhadap budaya lokal.

\section{Tinjauan Pustaka}

Pendidikan adalah interaksi manusia bertemu dengan keragaman manusia. Baik keragamaman agama, etnis dan ras (Langgulung 2003:102) ,pendidikan seharusnya berpengaruh pada nilai -nilai moderasi beragama pada siswa yang di dapatkan dari berbagai sumber Literasi, pengalaman pribadi, lingkungan madrasah, lingkungan keluarga, guru yang memberikan pendidikan dan pengajaran tentang keragaman (Haitami Salim 2012:24).

Pemahaman moderasi beragama terlihat pada pemahaman kognitif, afektif dan psikomotorik dan implementasi pada keragaman pemahaman Mazhab dan Guru dan dapat mengimpementasikan paham sikap kerukunan antar ummat beragama dan suku. (Harahap, 2011:78). moderasi beragama dianalisis dengan memakai teori taksonomi Bloom. Pemahaman dengan mengaplikasikan harus diawali dengan pengetahuan (Utari, 2016:3). Krathwohl, mengembangkan teori Bloom sebagaimana teori yang di pakai Menurut Lorin, teori Krathwohl, adalah ingatan , pemahaman , implementasi (Krathwohl, 2002: 212-218).

Memahami pelajaran adalah "kemampuan seseorang untuk mengerti atau memahami sesuatu setelah diketahui dan diingat". Memahami pelajaran merupakan ajang tingkat rasio selevel lebih tinggi di banding tingkat khafalan" Anas Sudijono (2010:50) Memahami adalah tidak menghafal pelajaran akan tetapi memahami struktur pelajaran tersebut. Yusuf Anas (2009:151 )

Pendidikan moderasi beragama adalah sebuah usaha memahami dan menumbuhkan pemahaman pada keberagaman agama, (mazhab) etnis, ras dan budaya (Suardi, 2015:55). Indikator moderasi beragama ada 4 yakni ; 1) loyalitas pada cinta tanah air 2) tidak fanatik, 3) Kerukunan/anti kekerasan, dan 4) mengakomodir kebiasaan daerah / setempat.Namun dalam penelitian ini hanya melihat dua indikator yakni toleransi dan akomodatif terhadap budaya lokal.

Toleransi identik dengan tidak mengklaim bahwa agamanya yang paling benar beragama yang menjadi tekanan adalah toleransi antar agama dan toleransi intra agama, baik terkait dengan toleransi sosial maupun politik. . (L. Eck, 2006: 1).

Namun seorang intelektual lain, yaitu Walzer memberikan klasifikasi menjadi 4 
1) Tidak fanatik pada pemahaman nya 2) perbedaan adalah keragaman, 3) Menghargai pemahaman orang lain 4) Menimplementasikan sikap keragaman , dan 5) Memahami keragaman (Walzer, 1997:57).

Akomodatif terhadap budaya lokal adalah dengan melihat sejauh mana kesediaan memahami budaya budaya suku lain dan menerima praktik beragama yang didasarkan pada keutamaan, tentu, sekali lagi, sejauh praktik itu tidak bertentangan dengan hal yang prinsipil dalam ajaran agama. Sebaliknya, ada juga kelompok yang cenderung tidak akomodatif terhadap tradisi dan kebudayaan, karena mempraktikkan tradisi dan budaya dalam beragama akan dianggap sebagai tindakan yang mengotori kemurnian agama. Pandangan bahwa seseorang yang semakin akomodatif terhadap tradisi lokal, akan semakin moderat dalam beragama memang masih harus dibuktikan. Bisa jadi, tidak ada korelasi positif antara sikap moderat dalam beragama dengan akomodasi terhadap tradisi lokal dalam beragama.

\section{METODE PENELITIAN}

Metode menggunakan kualitatif, tekhnik pengumpulan data melakukan pengamatan langsung dan mewawancarai beberapa informan di Madrasah Aliyah Swasta (MAS) Muhammadiyah Isimu Tibawa Kabupaten Gorontalo.

\section{Pembelajaran Pendidikan Moderasi Beragama Peserta Didik di MAS Muhammdiyah Isimu Kabupaten Gorontalo}

\section{Profil Madrasah}

Madrasah Aliyah Muhammadiyah Isimu, dengan status Akreditas Madrasah "A". terletak di jalan Siswa No. 22 Desa Tolotio, Kecamatan Tibawa Kabupaten Gorontalo. Yang di pimpin oleh seorang Kepala Madrasah Dra Hartati Dai. Madrasah tersebut berada dibawah naungan Yayasan Muhammadiyah tepatnya di Kelurahan Hunggaluwa, Kecamatan
Limboto. Madrasah memiliki luas Tanah kampus cukup memadai yang terletak di posisi jalan poros kabupaten menuju bandara Jalaluddin Gorontalo. dengan status Bangunan : Pemerintah dan Yayasan, Madrasah Aliyah Muhammadiyah memiliki Guru/Pegawai diuraikan sebagai berikut : Guru Tetap sebanyak 5 orang perempuan, Guru Tetap bersertifikasi sebanyak 5 orang perempuan, Guru Tidak Tetap sebanyak 5 laki-laki dan 5 perempuan, Guru Tidak Tetap Sertifikasi 1 laki-laki dan 2 perempuan, sedangkan Pegawai tetap dan Pegawai Tidak Tetap tidak ada. Total jumlah Guru dan Pegawai sebanyak 23 orang terdiri dari 6 laki-laki dan 17 perempuan. Kualifikasi pendidikan guru terbagi atas Program S2 sebanyak 1 orang, Program S1 sebanyak 14 orang dan 18 orang berpendidikan SMA atau setara.

Data keadaan siswa menurut Kelas, Program dan Jenis Kelamin diuraikan sebagai berikut : Kelas X Program Umum $\mathrm{X}$ A terdiri dari 15 laki-laki dan 11 perempuan, Kelas X Program Umum X B terdiri dari 14 laki-laki dan 11 perempuan, Kelas XI Program IPA terdiri dari 9 lakilaki dan 13 perempuan, Kelas XI Program IPS 11 laki-laki dan 8 perempuan, Kelas XII Program IPA 10 laki-laki dan 7 perempuan, dan Kelas XII Program IPS 18 laki-laki dan 6 perempuan. Total jumlah siswa Kelas X, Kelas XI dan Kelas XII Program Umum, Program IPA dan Program IPS sebanyak 133 orang yang terdiri dari 77 laki-laki dan 56 perempuan yang terbagi dalam 6 Rombongan Belajar.

Data sarana dan prasarana pendidikan yang dimiliki madrasah berdasarkan jenis sarana antara lain Ruang Kelas, Ruang Perpustakaan, Ruang Lab Komputer,Ruang Pimpinan Madrasah, Ruang Guru, Ruang Ibadah, Ruang OSIS, Ruang Unit Kesehatan Sekolah, Ruang Bimbingan Konseling, Toilet Guru dan Toilet Siswa.

Organisasi Siswa Intra Sekolah (OSIS) adalah organisasi yang diselenggarakan oleh peserta didik di madrasah dan dibina oleh bidang kepeserta didikan, untuk kepentingan peserta didik 
dalam menunjang dan meningkatkan kualitas kegiatan belajar mengajar, OSIS merupakan media pembelajaran demokrasi dan organisasi bagi peserta didik, Setiap peserta didik diharuskan menjadi anggota OSIS dan bersedia diangkat menjadi pengurus OSIS sesuai dengan ketentuan yang berlaku, Perangkat OSIS terdiri dari: Pembina OSIS, Musyawarah Perwakilan Kelas (MPK), Pengurus OSIS.

Pembina OSIS dan ekstrakurikuler ditunjuk oleh kepala madrasah sesuai kapasitas, kemampuan, dan itikad kesungguhan guru yang bersangkutan setiap sekali setahun, MPK dan pengurus OSIS dipilih setiap satu tahun sekali, menurut kaidah demokrasi dan disahkan oleh madrasah, Setiap pergantian pengurus, harus disertai dengan laporan pertanggungjawaban kegiatan dan keuangan.

Kegiatan Ekstrakurikuler adalah kegiatan yang diselenggarakan oleh madrasah sebagai suplemen dari usaha pengembangan potensi, bakat, dan karakter peserta didik, Kegiatan ekstrakurikuler diprioritaskan bagi Kelas X dan Kelas XI, Penilaian kegiatan ekstrakurikuler bersifat kualitatif dan dicantumkan dalam Buku Laporan Pendidikan (BLP), Organisasi ekstrakurikuler madrasah terdiri dari: Pramuka, OSIS, PMR, Organisasi ekstrakurikuler yang bernaung di bawah OSIS. Setiap peserta didik dapat memilih 1 (satu) ektrakurikuler dan maksimal 2 (dua) ektrakurikuler, dengan persetujuan orang tua/wali dan sepengetahuan wali kelas yang bersangkutan. Kegiatan ektrakurikuler dilaksanakan setiap sore, setelah proses pembelajaran, serta Hari Sabtu pagi dan sore. Batas waktu kegiatan ekstrakurikuler pada sore hari adalah Pukul 17.00 WITA. Penilaian kegiatan ekstrakurikuler bersifat kualitatif dan dicantumkan dalam buku laporan pendidikan/ARD. Peserta didik yang mempunyai nilai akademis kurang, dilarang mengambil ekstrakurikuler lebih dari 1 (satu) kegiatan ekstrakurikuler.

Pelaksanaan kegiatan ekstrakurikuler dijadwalkan sesuai kondisi madrasah.
Kegiatan ekstrakurikuler yang tidak dijadwalkan pada hari yang ditentukan, dilarang mengadakan kegiatan/pertemuan, kecuali pada keadaan tertentu (persiapan mengikuti lomba/pertandingan, akreditasi, $\mathrm{dsb}$ ). Tidak diperkenankan mengadakan kegiatan ekstrakurikuler pada Hari Ahad, kecuali pada keadaan tertentu. Kegiatan ekstrakurikuler yang mengadakan kegiatan bukan pada jadwal yang ditentukan, akan dibubarkan paksa. Kegiatan ekstrakurikuler yang sering melanggar aturan, kepada pengurus tersebut akan dikenakan sanksi.

Kegiatan Keagamaan. Peserta didik diharuskan membudayakan $3 \mathrm{~S}$ (senyum, salam, sapa). Berperilaku hormat, sopan, dan santun kepada guru/pegawai, sesama peserta didik, orang tua/wali peserta didik, dan tamu. Setiap Hari Selasa dan Kamis peserta didik diharuskan mengikuti tadarus al-qur'an, sebelum pelaksanaan apel pagi. Setiap Hari Jum'at setelah pelaksanaan sholat dhuha, peserta didik diharuskan mengikuti uji publik program tahfidz qur'an. Peserta didik yang tinggal di asrama madrasah diwajibkan mengikuti program keagamaan di asrama madrasah (jadwal pelaksanaan kegiatan keasramaan diatur tersendiri).

Sholat Duha: Setiap Hari Senin, Rabu, dan Jum'at peserta didik wajib mengikuti sholat dhuha. Peserta didik diharuskan berwudhu dari rumah sebelum tiba di madrasah. Peserta didik putri yang berhalangan diwajibkan berada di taman literasi.

Sholat Dzuhur dan Ashar: Peserta didik diwajibkan sholat dzhur/ashar di masjid madrasah secara berjamaah. Peserta didik secara bergilir per kelas membawakan kultum sebelum pelaksanaan sholat dzuhur. Peserta didik diharuskan berada di dalam masjid saat iqamat dikumandangkan.

Sholat Jum'at: Bagi putra diwajibkan sholat jum'at di masjid madrasah. Peserta didik sudah berada di dalam masjid sebelum khutbah dimulai. Mengambil shaf/duduk diantara jamaah lainnya dengan posisi menghadap ke kiblat. Dilarang berbicara saat khutbah berlangsung. Peserta 
didik diharuskan menjaga ketertiban, kebersihan, dan kekhusyu'an beribadah. Peserta didik diharuskan mengikuti pelaksanakan peringatan Hari-Hari Besar Agama Islam yang dilaksanakan di madrasah.

Pengembangan diri diarahkan untuk mengembangkan karakter peserta didik yang dibentuk melalui sikap, pengetahuan dan keterampilan, dan dikemas dalam budaya madrasah yaitu santun berbahasa, santun bertindak, dan santun berpakaian. Budaya madrasah disebar melalui programprogram yang secara rutin dilaksanakan. Program pengembangan diri, perencanaan dan pelaksanaan pendidikan budaya dan karakter bangsa dilakukan melalui pengintegrasian ke dalam kegiatan seharihari madrasah yaitu melalui hal-hal berikut: Kegiatan rutin madrasah. Kegiatan rutin merupakan kegiatan yang dilakukan peserta didik secara teru menerus dan konsisten setiap saat. Contoh kegiatan ini adalah upacara bendera, tadarus, beribadah bersama atau shalat bersama setiap dhuhur, berdoa waktu mulai dan selesai pelajaran, mengucap salam apabila bertemu guru, tenaga kependidikan atau teman.

Kegiatan Spontan. Kegiatan spontan yaitu kegiatan yang dilakukan secara spontan pada saat itu juga. Kegiatan ini dilakukan biasanya pada saat guru dan tenaga kependidikan yang lain mengetahui adanya perbuatan yang kurang baik dari peserta didik yang harus dikoreksi saat itu juga. Apabila ada yang mengetahui adanya perilaku dan sikap yang kurang baik maka pada saat itu juga guru harus melakukan koreksi sehingga peserta didik tidak akan melakukan tindakan yang tidak baik itu. Contoh kegiatan itu : membuang sampah tidak pada tempatnya, berkelahi, berlaku tidak sopan, mencuri, berpakaian tidak senonoh. Kegiatan spontan berlaku untuk perilaku dan sikap peserta didik yang tidak baik dan yang baik sehingga perlu dipuji, misalnya : memperoleh nilai tinggi, menolong orang lain, memperoleh prestasi dalam olah raga atau kesenian, berani menentang atau mengkoreksi perilaku teman yang tidak terpuji.

Keteladanan. Keteladanan adalah perilaku dan sikap guru dan tenaga kependidikan yang lain dalam memberikan contoh terhadap tindakan-tindakan yang baik sehingga diharapkan menjadi panutan bagi peserta didik untuk mencontohnya. Misalnya santun berbicara, santun berpakaian, santun bertindak, datang tepat pada waktunya, bekerja keras, kasih sayang, perhatian terhadap peserta didik, jujur, menjaga kebersihan.

Pengkondisian. mencerminkan kehidupan nilai-nilai budaya dan karakter bangsa yang diinginkan. Misalnya, toilet yang bersih, bak sampah di berbagai tempat dan selalu dibersihkan, lingkungan madrasah rapi, dan alat belajar yang teratur.

Pengintegrasian dalam mata pelajaran. Nilai-nilai tersebut dicantumkan dalam silabus dan RPP. Pengembangan nilai itu dalam silabus ditempuh melalui cara-cara berikut ini : Mengkaji Standar Kompetensi (SK) dan Kompetensi Dasar (KD) pada Standar Isi (SI) untuk menentukan apakah nilai-nilai budaya dan karakter bangsa yang tercantum itu sudah tercakup di dalam; Mengkaji keterkaitan antara SK dan KD dengan nilai dan indicator untuk menentukan nilai yang dikembangkan; Mencantumkan nilai-nilai budaya dan karakter bangsa ke dalam silabus; Mencantumkan nilai-nilai yang sudah tertera dalam silabus ke dalam RPP; Mengembangkan proses pembelajaran peserta didik secara aktif yang memungkinkan peserta didik memiliki kesempatan melakukan internilasasi nilai dan menunjukkanya dalam perilaku yang sesuai; dan Memberikan bantuan kepada peserta didik, baik yang mengalami kesulitan untuk menginternalisasi nilai maupun untuk menunjukkanya dalam perilaku.

Pengaturan Beban Belajar. Beban belajar dalam sistem paket digunakan oleh tingkat satuan pendidikan. Jam pembelajaran untuk setiap mata pelajaran 
pada sistem paket dialokasikan sebagaimana tertera dalam struktur kurikulum. Pengaturan alokasi waktu untuk setiap mata pelajaran yang terdapat pada semester ganjil dan genap dalam satu tahun ajaran dapat dilakukan secara fleksibel dengan jumlah beban belajar yang tetap. Penetapan beban belajar kelas X meliputi: Alokasi waktu untuk penugasan terstruktur (PT) dan kegiatan mandiri tidak tersturktur (KMTT) maksimal 60\% dari waktu kegiatan tatap muka per minggu mata pelajaran bersangkutan; Alokasi waktu untuk tatap muka setiap jam pelajaran 45 menit; Jumlah jam pelajaran perminggu untuk kelas X dan Kelas XI adalah 51 jam pelajaran.

Untuk kelas XII penetapan beban belajar selama kurun waktu tiga tahun atau enam semester di MA dilakukan melalui penyetaraan dengan beban belajar sistem paket sesuai dengan ketetapan Permendiknas Nomor 22 tahun 2006 tentang Standar isi. Dalam Permendiknas tersebut ditetapkan struktur kurikulum dalam satuan jam pelajaran berdasarkan sistem paket terdiri dari tatap muka (TM), tugas terstruktur (TT), dan kegiatan mandiri (KM).

Penugasan struktur adalah kegiatan pembelajaran yang berupa pendalaman materi pembelajaran oleh peserta didik yang dirancang oleh pendidik untuk mencapai standar kompetensi. Waktu penyelesaian penugasan struktur ditentukan oleh pendidik. Adapun kegiatan mandiri tidak terstuktur adalah kegiatan pembelajaran yang berupa pendalaman materi pembelajaran oleh peserta didik yang dirancang oleh pendidik untuk mencapai standar kompetensi. Waktu penyelesaiannya diatur sendiri oleh peserta didik.

Pemanfaatan alokasi waktu untuk penugasan terstruktur dan kegiatan mandiri tidak terstruktur tersebut mempertimbangkan potensi dan kebutuhan peserta didik dalam mencapai kompetensi. Jumlah jam pelajaran perminggu adalah sebagai berikut: Kelas XII semester 1 dan 2 adalah 47 jam pelajaran ada penambahan mata pelajaran ciri khas program.

Muatan lokal merupakan kegiatan kurikuler untuk mengembangkan kompetensi yang disesuaikan dengan ciri khas dan potensi daerah, termasuk keunggulan daerah, dengan tujuan memberikan kesempatan kepada peserta didik untuk mengembangkan diri sesuai dengan kebutuhan, bakat, minat dan kondisi madrasah. Berdasarkan hal tersebut maka pengembangan muatan lokal disesuaikan dengan pelaksanaan kurikulum. Kelas X dan XI (Kurikulum 2013)

Budaya lokal hubungan nya dengan keadaan dan kebutuhan daerah. Keadaan daerah adalah segala sesuatu yang terdapat di daerah tertentu yang pada dasarnya berkaitan dengan lingkungan alam, lingkungan sosial ekonomi, dan lingkungan sosial budaya. Kebutuhan daerah adalah segala sesuatu yang diperlukan oleh masyarakat di daerah, khususnya untuk kelangsungan hidup dan peningkatan taraf kehidupan masyarakat tersebut, yang disesuaikan dengan arah perkembangan daerah serta potensi daerah yang bersangkutan. Kebutuhan daerah tersebut adalah seperti kebutuhan untuk: melestarikan dan mengembangkan budaya daerah, meningkatkan kemampuan dan ketrampilan di bidang tertentu sesuai dengan keadaan perekonomian daerah, meningkatkan kemampuan kewirausahaan. Lingkup isi/jenis muatan lokal. Lingkup isi/jenis muatan lokal dapat berupa: kemuhammadiyahan (Kepala Madrasah Aliyah Muhammadiyah ISIMU)

\section{Pemahaman dan praktik-praktik nilai- nilai Moderasi Beragama melalui kegiatan Ekstrakurikuler}

Sekilas mengenai kebijakan madrasah yang berkaitan dengan menghargai keragaman siswa dan guru secara khusus belum ada, namun diimplementasikan pada visi misi madrasah sebagai pusat keunggulan pendidikan agama berdasarkan 5 budaya kerja yang ada di madrasah yakni inovasi, profesionalitas, 
tanggungjawab, dan keteladanan. Budaya di madrasah dilaksanakan ketika siswa masuk kelas, terlihat guru yang bertugas sebagai guru piket yang bertugas untuk melakukan sambutan kepada siswa dengan sikap senyum, salam dan sapa pada semua siswa tanpa membedakan suku, agama dan ras.

Demikian halnya dengan siswa lakilaki melakukan salaman dengan laki-laki pula. Siswa dibiasakan untuk tidak bersalaman selain muhrim, ini salah satu cara untuk mengimplementasikan nilainilai agama. Oleh karenanya apabila siswa ingin bersalaman dengan lain jenis cukup dilakukan dengan menundukkan kepala atau hormat karena semua siswa bak lakilaki maupun perempuan sudah berwudhu dari rumah untuk melaksanakan shalat dhuha di madrasah. Selain budaya tersebut terdapat budaya yang sangat kental di madrasah ini yakni kegiatan shlat dhuhur yang dlaksanakan tiap hari secara berjamaah di mushallah yang telah disediakan. Budaya yang tidak dapat dilanggar di madrasah dan merupakan suatu aturan yang harus ditaati yaitu tidak boleh merokok, bawa hp, melakukan pertemuan khusus laki-laki dan wanita. Cara bermedia sosial yang mengharagai perbedaan dilakukan di luar jam pelajaran di madrasah karena hal tersebut tidak dapat dilakukan di madrasah.

Perkembangan literasi yang kerap kali dibaca oleh siswa terdapat di perpustakaan dan literasi digital yang didapatkan melalui internet mengenai pluralisme agama. Budaya madrasah yang berlaku di sekolah ini yakni saling diskusi berbagi ilmu diantara siswa yang dibina oleh senior pembina dari mazhab yang berbeda-beda. Mazhab yang terdapat di madrasah tersebut yang digandrungi oleh siswa adalah mazhab salafih, wahdah, muhammadiyah, NU, jamaah tabliq. Keragaman mazhab tersebut cukup menarik perhatian dianatar para siswa mereka saling berlomba untuk melakukan aktifitas diantaranya melakukan pengajian training masalah tata cara berbicara dihadapan orang banyak. Semua kegiatan tersebut mengarah ke hal-hal yang positif dan keragaman tersebut mengarah kepada kerukunan dan damai.

Program unggulan madrasah kegiatan tahfiz quran yang dilaksanakan setap inggu yakni pada hari yang telah ditentukan oleh madrasah hari sabtu waktunya mulai pagi sampau menjelang shalat dhuhur dan selanjutnya melaksanakan shalat dhuhur berjamaah dan dilanjutkan dengan kegiatan kuliah tujuh menit (kultum). Kegiatan tahfiz tersebut dilakukan dengan menyetor hafalan ke pembina tahfiz alquran yang telah ditugaskan sebanyak minimal satu orang. Lain halnya pembina tahfiz alquran yang telah ditugaskan di asrama berjumlah 2 orang. Hal tersebut dilakukan untuk mengintensifkan hafalan alquran di asrama. Hafalan alquran dilakukan di madrasah dalam satu pekan volumenya dilaksanakan 3 kali shalat dhuhur berjamaah pada hari yang telah ditentukan oleh pembina madrasaj yaitu hari jumat. Hal ini dilaksanakan sebelum masuk ke ruang kelas yakni pukul 06.45 sampai dengan pukul 07.15 pagi.

Selanjutnya hafalan alquran ini diintensifkan oleh guru pembina dengan melakukan uji publik tahfiz dengan tehnik yangtelah disepakati bersama oleh pembina tersebut. Salah satu tehnik yang diimplementasikan di madrasah tersebut yakni ketika siswa diuji mereka berdiri di depan pembina, selanjutnya siswa yang lainnya boleh menguji pada siswa yang sedang mendengarkan bacaan alquran dengan membacakan sebagaian ayat dan dilanjutkan oleh orang yang sedang diuji publik. Ujian tahfiz alquran yang dilaksanakan di madrasah tersebut terdapat beberapa tehnik dalam melaksanakan uji publik yakni tahfiz ada yang menghafal 3 juz dan ada pula yang menghafal 5 juz dan diantara sekian siswa yang menghafal alquran maka uji publik yang terbanyak menghafal alquran berasal dari laki-laki yakni 7 juz. (Wawancara, wakil kepala Madrasah bagian Kurikulum) 
Selain kegiatan tahfiz alquran tersebut, budaya sekolah telah mengimplementasikan pendalaman fiqhi ibadah dengan materi bacaan ayat-ayat suci alquran ketika melakukan shalat. Selain budaya tersebut masih ada budaya yang mengarah kepada kegiatan keagamaan yakni memperbaiki tata cara berwudhu, dan tata cara shalat, memperbaiki tata cara bacaan ketika melaksanakan shalat wajib dan shalat sunnah. Selain hal tersebut di atas siswa biasanya setiap sekali seminggu hari jumat sore melaksanakan kegiatan latihan memandikan jenazah dan sekaligus mengaarkan epada siswa tata cara melaksanakan shalat jenazah.

Budaya madrasah sudah menjadi kebutuhan siswa dan guru salah satu diantaranya melakukan kerja bakti untuk membersihkan masjid yang dilaksanakan pada setiap hari jumat sebelem shalat jumat dilaksanakan. Selain kegiatan tersebut, budaya yang rutinitas dilaksanakan di madrasah, OSIS melaksanakan implementasi pembelajaran kemuhammdiyahan diantaranya tata cara shalat yang menurut keputusan majelis tarjih yang dilaksanakan pada hari jumat.( Guru Muatan Lokal MA Muhammadiyah ISIMU)

Pemahaman peserta didik mengenai moderasi beragama didapatkan dari mata kegiatan pembelajaran intrakurikuler dan ekstrakurikuler.

Pembelajaran intrakurikuler di peroleh dari beberapa mata pelajaran diantaranya adalah Al-Qur'an dan Hadis. Memahami dan mengamalkan isi pokok Al-Qur'an surat Al Hujarat ayat (13) mengenai keanekaragaman suku dan bangsa, sesungguhnya kami ciptakan pria dan wanita dan menciptakan kalian keragaman budaya supaya kalian silaturrahmi itulah kemuliaan Allah bagi orang melaksanakan ketentuan Allah. Ayat di atas menegaskan bahwa membiasakan diri untuk hidup bertoleransi dengan mazhab yang berbeda antar lain agama, saling menghormati, tolong menolong dalam masalah kebaikan. (Wawancara dengan Andrini S. Mangopa, Siswa Kelas $\mathrm{XI})$.

Mata pelajaran Hadis tentang manusia atau pemimpin yang harus bersikap demokrasi dan bertanggung jawab di muka bumi ini dengan cara menghargai keragaman suku, agama, ras dan budaya. Hadis tersebut menyatakan "Kalian semua adalah Khalifah selanjutnya masing-masing Khalifah akan di minta pertanggungjawaban atas kenerjanya Hadist tersebut menegaskan bahwa pemimpin yang baik adalah yang mampu bersikap demokratis, tidak memihak pada satu golongan dan memahami kebhinekaan SARA yang ada di sekitarnya. (Wawancara dengan Sri Resti Fadilla Ramadhani, Siswa Kelas XI).

Pemahaman peserta didik mengenai Kebhinekaan didapatkan dari mata pelajaran Akidah Akhlak. Pelajaran Akidah untuk memahami Akidah, prinsip-prinsip , wawasan keragaman aliran-aliran atau perbedaan pemahaman dalam akidah menjadi pedoman mengimlementasikan pemahaman agama .Pelajaran Akhlak ,implementasi mengenai akhlak yang baik dan menjauhi akhlak yang tidak terpuji dan diimplementasikan baik dalam kehidupan di Madrasah dan di luar Madrasah (Wawancara dengan Dwi Melfa Bilatula, Siswa MAS Muhammadiyah Tibawa).

Pemahaman kebhinekaan peserta didik didapatkan dari mata pelajaran Fiqh, materinya aspek ibadah dan Muamalat ,terdiri dari hubungan nya dengan pelaksanaan beribadah dan Syaria,at:, (saling mengenal dan memahami keragaman pemahaman keagamaan aliran lain sehingga tidak menganggap bahwa paham alirannya lah yang paling benar, hubungan manusia dengan makhluk lainnya ataupun lingkungannya.(Wawancara dengan Rahman Yusuf, Siswa Kelas XI).

Pemahaman Kebhinekaan peserta didik diperoleh melalui materi pelajaran PPKN terdapat pada materi kebhinekaan bangsa Indonesia pada Kelas X, Demokrasi Nasional, Mata pelajaran Sosiologi materinya multikultural pada Kelas X dan 
metode pemecahan masalah konflik antar agama, negara, etnis/suku pada Kelas XI, kompetensi dasar memahami dan menerima perbedaan antar umat beragama , menghayati penyebab fenomena yang menyebabkan konflik antar suku, agama dan budaya. Mata pelajaran Antropologi materinya persamaan dan perbedaan Budaya, Keragaman Budaya (Wawancara Nasir MAS Muhammadiyah ISIMU).

Materi - materi tersebut di atas biasanya telah mengetahui, memahami dan mengimlementasikan Pendidikan moderasi beragama melalui pembelajaran intrakurikuler dan ekstrakurikuler.

Pemahaman kebhinekaan didapatkan salah satunya dari pelajaran muatan lokal yang unggul di MAS Muhammadiyah Isimu adalah kemuhammadiyahan yang terdiri dari 2 jam pelajaran setiap minggu untuk satu rombongan belajar. Selain hal tersebut budaya yang dilaksanakan di madrasah ini adalah shalat duha sebelum dilaksanakan pembelajaran. Selain hal tersebut pengkaderan Ikatan Pelajar Muhammdiyah (IPM) yang dilaksanakan di madrasah dan salat dhuhur dan siswa diwajibkan untuk melaksanakan kultum. Pemahaman kebhinekaan pada siswa tetap menghargai budaya namun pada perayaan valentine dan natal peserta didik tetap diberikan pemahaman bahwa perayaan itu bukan hari raya Islam, hari Islam adalah tahun baru hijriah namun tetap menghargai tapi tidak ikut merayakan. Ketika hari raya "Ketupat" peserta didik sudah masuk sekolah sehingga yang mengikuti perayaan tersebut hanya peserta didik yang berdomisili di Kampung Reksonegoro khusus kampung orang Jawa Tondano yang wajib melaksanakan selama 7 hari raya ketupat.(Wawancara dengan Dra. Hartati Dai, Kepala MAS Muhammadiyah Isimu Tibawa).

Memahami budaya di intra dan ekternal Madrasah. madrasah siswa harus mematuhi tata tertib dan menghargai pendapat orang lain . Pengalaman menarik yang siswa dapatkan bergaul dengan orang yang selalu mengajak dalam hal kebaikan misalnya belajar agama di suatu kajian atau komunitas hijrah lainnya di sekolah juga banyak temannya saling bertukar pendapat. Di luar madrasah dapat bergaul dengan suku agama yang berbeda namun susah berbaur dengan masyarakat dan bacaan buku yang saya suka adalah Tuntunan Shalat untuk wanita dan Judul buku Untuk Apa Saya Harus Shalat. Youtube yang biasa saya tonton tentang pengalaman hijrah. Pengalaman tentang SARA yang biasa disebut oleh guru yaitu Ras, perbedaan antar golongan, suku agama dan bahasa maupun warna kulit mengenai ras, warna kulit tidak menutup kemungkinan orang berkulit hitam hanya berada di papua dan ternyata berasal dari keturunan dan daerahnya masing-masing . Jika yang berkulit putih yang paling menonjol di Negara Cina akan tetapi tidak menutup kemungkinan juga berada di Indonesia seperti di Manado. Pemahaman SARA di lingkungan keluarga dalam kebhinekaan beragama yang paling menonjol dalam keluarga dari pelaksanaan doa satu hari, dua hari sampai 40 hari pada pelaksanaan orang yang telah meninggal dan doa arwah lainnya. Kebhinekaan ras juga ada yang berbeda dalam keluarga warna kulit, rambut dan lain-lain. Pengalaman saya melalui media sosial yaitu mengenai perbedaan pendapat tentang agama, suku dan budaya karena setiap daerah memiliki perbedaan ragam bahasa. (Wawancara dengan Dwi Melfa Bilatula, Siswa MAS Muhammadiyah Tibawa).

Buku literatur yang biasa dibaca hubungannya dengan keragaman buku PPKN, biasanya hanya buku yang sering diajarkan setiap hari oleh guru PPKN, buku agama yang dibaca Buku Fiqhi, Al-qur'an Hadis dan Akidah Akhlak. Fadhilah amal, fadhilah sodoqoh, hayakus sahabah, Mubakhas Hadis.(Wawancara dengan Nasir MAS Muhammadiyah ISIMU).

Adat istiadat yang dialami di lingkungan madrasah pada komunitas di luar madrasah adalah Jawa Tondano dan berbahasa Hulondalo. Kebhinekaan suku menceritakan adat istiadat, kesenian, atau 
komunikasi ataupun bahasa. Aliran atau organisasi yang berkembang di madrasah adalah Ikatan Pelajar Muhammadiyah. Pertemanan dengan orang yang berbeda ras adalah tetap saling menghargai antar suku ras dan golongan, tidak saling mencaci maki. (Wawancara dengan Ibrahim, Siswa MAS Muhammadiyah Tibawa, Kajian di Masjid Halid Bin Walid, Materi Sunnah2 Nabi , Dosa-2 Besar dan Kecil).

Perbedaan dari warna kulit, jenis rambut, perawakan tinggi badan, mata sipit dan lain-lain, kebhinekaan suku menceritakan adat istiadat, kesenian, atau komunikasi ataupun bahasa, kebhinekaan agama pembahasan aliran Islam atau suatu kelompok organisasi atau disebut dengan kajian keagamaan. Kebhinekaan antar golongan/budaya yang semakin maju dan pengalaman setiap orang yang telah dijalankan misalnya perkembangan daerah Gorontalo di Masjid Agung Limboto, Masjid Besar Baiturrahman Isimu).

Budaya yang berkembang di masyarakat pada lingkungan Madrasah Aliyah Muhammadiyah adalah hari raya Ketupat. Pada hari raya tersebut dilaksanakan pada hari ketujuh pasca hari raya idul fitri yang dilaksanakan di masjidmasjid dengan melaksanakan zikir bersama mulai dari jam 06.oo pagi sampai dengan jam 10.00 pagi dan selanjutnya menyiapkan makanan dan minuman di sepanjang jalan yang diperuntukkan bagi semua masyarakat yang ingin menikmati perayaan hari raya ketupat yang dikenal dengan 10.000 ketupat yang disebar di sepanjang jalan dan pemerintah dari provinsi, kabupaten/kota ikut merayakan kegiatan tersebut. Hari raya tersebut berawal dari perayaan hari raya Islam Jawa Tondano yang berada di kampung Reksonegoro yang biasa disingkat Jaton (Jawa Tondano), komunitas tersebut terletak kurang lebih 3 kilometer dari MAS Muhammadiyah Tibawa. (Wawancara dengan Dwi Melfa Bilatula, Kelas X Pake Cadar , Siswa MAS Muhammadiyah Tibawa, Kajian di Masjid Agung Limboto, Masjid Besar Baiturrahman Isimu).
Dari beberapa hasil wawancara di atas mata pelajaran yang di laksanakan pada kegiatan intrakurikuler tersebut dan ekstrakuler adalah nilai-nilai Moderasi beragama telah di pahami dan di implementasikan oleh Siswa yakni tidak mengklaim bahwa pemahaman agama (Mazhab) yang paling benar namun saling menghargai keragaman antar pemahaman diantara keragaman mazhab yang ada di Madrasah tersebut (Dian Dkk, 2014: 90).

Beberapa hasil wawancara tersebut mulai terlihat siswa waajib beradaptasi pada kondisi perbedaan tersebut.siswa terlihat memahami keragaman pemahaman. Dengan tidak melihat Mazhab yang ada . hal ini memberikan motivasi untuk menghargai keragaman yang ada . memahami keragaman sebagaiman teori matra Walzer (1997) pada posisi tahap selanjutnya, yaitu mengimplementasikan keragaman, Diana L Eck mengatakan suatu perbedaan dan posisinya sama tidak ada perbedaan diantara keragaman tersebut (L-Eck, 2006: 1).

Dwi Melfa Bilatula dan Nasir, mampu menjelaskan dengan gamblang. Dan mampu mengaplikasikan melalui kegiatan ekstrakurikuler di Madrasah dan dapat beradaptasi di masyarakat sekitarnya dengan mengakomodir budaya lokal yang dilaksanakan di lingkungan Madrasah , menghargai perbedaan paham Mazhab dengan ikut berpartisipasi ketika acara budaya hari raya ketupat, mengaplikasikan nilai-nilai moderasi beragama mengenai “ Hidup Bersama dengan kemajemukan" oleh Guru dan Siswa, Nampak saling menghargai dari berbagai peserta didik yang berbeda Mazhab atau SARA. Kultum di Masjid misalnya, peserta didik ini terlihat saling menghargai ketika mengemukakan faham keagamaan yang berbeda di antara peserta didik.

Tasamuh merupakan proses pembelajaran pada peserta didik agama Islam dapat di pahami derada pada memahami keragaman sesuai dengan teori dari toleransi Walzer (1997), kata kuncinya adalah tasamuh. Inilah yang menjadi topik 
inti dalam pembelajaran Islam yakni kemuhammadiyahan sebagai pelajaran muatan lokal yang memuat di dalam nya masalah nilai-nilai moderasi beragama pada MAS Muhammadiyah Isimu Gorontalo.

Pada peserta didik muslim yang ada di MAS Muhammadiyah Isimu Tibawa Gorontalo, Kemuhammadiyahan adalah sebagai dasar pemahaman nilai-nilai Moderasi beragama kunci untuk memberikan pemahaman untuk saling menghargai keragaman yang ada,Alqu'ran surat Al Hujarat ayat 13 : "Hai manusia sesungguhnya kami menciptakan kamu dari seorang laki-laki dan perempuan dan menciptakan berbangsa-bangsa dan bersuku-suku supaya kamu saling kenal mengenal, sesungguhnya orang paling mulia di antara kamu adalah orang-orang yang paling bertaqwa di antara kamu" (AlHujarat: 13).

Mata pelajaran Tasamuh berdasarkan "Mengapa kita harus menerima keragaman?" Ketua paskibraka memulai penjelasannya soal toleransi. "Tidak lain karena keragaman itu sunnatullah, satu hal yang secara sengaja diciptakan oleh Allah, seperti dalam surat Al-Hujarat itu". keragaman adalah suatu ketentuan Allah. (Ketua Paskibraka MAS Muhammadiyah ISIMU Kab Gorontalo).

$\begin{array}{llr}\text { Keragaman yang } & \text { sesuai } & \text { semboyan } \\ \text { bangsa Indonesia } & \text { adalah } & \text { Ketika } \\ \text { menghadapi perbedaan } & \text { suku dan agama }\end{array}$ tetap saling menghargai dan tetap berinteraksi antar sesama manusia walaupun terdapat perbedaan dari suku maupun pemahaman dalam hal agama, (Mazhab) ,melakukan interaksi terutama kita sebagai warga negara Indonesia.walaupun berbeda namun komunikasi tetap terjalin dengan baik hingga saat ini.dan keragaman ini di dapatkan pengetahuan dari Guru PKN dan Guru agama. Tujuan dari semboyan bangsa Indonesia adalah walaupun asal ras dan suku berbeda namun kita tetap satu yakni NKRI selanjutnya cara mewujudkan jika paham semboyan Indonesia maka dengan sendirinya siswa akan mengetahui dan mengimplementasikan perbedaan sehingga tercipta toleransi dankerukunan (Nazzul Hilmi kelas XI MAS ISIMU MUH KaB Gorontalo )

Kebhinekaan yakni memepersatukan seluruh bangsa Indonesia karena jika bangsa Indonesia masing-masing hanya mementingkan golongannya maka NKRI mudah pecah belah karena cita-cita luhur bangsa Indonesia untuk menjaga persatuan dan kesatuan NKRI . Fungsi kebhinekaan bagi persatuan dan kesatuan bangsa Indonesia yaitu menanamkan rasa saling menghargai antar sesama walaupun berbeda suku, agama dan budaya. Karena keberagaman dapat mengembangkan pengetahuan mengenai budaya yang ada di daerah lain. Mengimplementasikan sikap toleransi di MAS Muhammadiyah ISIMU menurut salah satu Siswa mengatakan bahwa saling menghargai antar agama , salah satu contoh ketika Masjid berdampingan dengan gereja pada saat tiba waktu shalat duhur yang bertepatan dengan jam ibadah di gereja, maka masing-masing saling menghargai dengan cara mengecilkan volume pengeras suara Masjid. Kebhinekaan yang didapatkan melalui media sosial himbauan untuk menjaga keragaman dengan pesan jangan sampai persatuan hancur karena perbedaan. Oleh karenanya kita tidak bisa saling menghargai karena kemerdekaan bangsa ini bukan hanya hasil dari satu golongan tertentu tetapi dari usaha bersama. Berteman sebagaimana biasa dengan orang yang berbeda agama, ras dengan mengedepankan sikap toleransi misalnya saling menghargai dengan tidak menyinggung agama, suku dan ras terkadang saling bertukar cerita dengan tidak saling menghina ataupun menjatuhkan. (Ahmad Fadly, MAS MUH ISIMU).

Keragaman dalam lingkungan keluarga, perebdaan agama pengalaman saya, ayah saya muallaf, oma, opa dan keluarga sebelah papa agama Nasrani. Ketika bangun pagi di hari minggu saya siap-siap shalat subuh dan keluarga Nasrani 
siap-siap ibadah tetapi tetap bisa rukun. Pengalaman literasu mengenai keragaman setelah membaca sebuag buku mengenai keragaman terasa lebih senang berteman dengan yang berbeda suku agama dan ras karena membuat kita semaikin merasa kaya akan keberagaman. Pengalaman keragaman yang didapatkan dari guru ketika Kelas X adalah orang Bugis yang terkenal bahasanya agak keras namun hali itu membuat saya tetap menghargai dan menghormati karena beliau adalah seorang guru.

Kebhinekaan merupakan hal yang unik menurut, sebuah keberagaman membuat satu daerah menjadi kaya karena maksud dan tujuan kebinekaan agar supaya kita saling mengenal dan belajar saling menghargai serta menghormati sebuah perbedaan. Mewujudkan cita-cita luhur bangsa Indonesia mengenai kebhinekaan dengan mengedepankan persatuan tanpa ada rasis antar sesama.

Fungsi

kebhinekaan

mempertahankan persatuan dan kesatuan agar bisa saling menghargai dan toleransi antar sesama dan memahami kepribadian dengan mencintai perbedaan saling menghargai sesama, tidak membedabedakan dan tidak pilih teman. Pemahaman dan praktik kebhinekaan pengalaman mengenai ras dilingkungan madrasah, pernah berteman sekelas orang dengan suku Minahasa namun tetap berteman dengan baik dan tidak menyinggung perbedaan yang ada dan keragaman budaya di lingkungan madrasah pada saat milad di madrasah daiadakan lomba tarian daeran dari 34 provinsi. (Wawancara dengan siswa Kelas XI).

Kebhinekaan diartikan perbedaan antar suku, ras, agama dan budaya. Pengalaman kebhinekaan pergaulan berteman yang berasal dari luar daerah Jayapura, Ambon dan Malang walaupun suku berbeda akan tetapi tetap satu dan hidup toleran serta tolong menolong dan tidak membedakan teman. Pengalaman literasi masalah keragaman walaupun kita berbeda agama, suku harus tetap satu karena dengan hal itu kita mewujudkan ketentraman dan kemakmuran sehingga cita-cita bangsa dapat terealisasi. Kebhinekaan yang didapatkan dari guru , guru menyikapi siswa dengan sangat baik tanpa membedakan keragaman tersebut bahkan guru selalu ikhlas dalam memberikan ilmu kepada siswa karena dia menginginkan kesuksesan dengan memberikan motivasi kepada siswa dengan memberikan pesan kalian adalah pemimpin masa depan karena kebhinekaan memiliki makna yang besar bagi NKRI yakni berbeda-beda akan tetapi tetap bersatu.

Maksud dan tujuan kebhinekaan agar terhindar dari sikap membedakan antar agama dan suku sehingga bhineka hadir untuk menyatukan masyarakat NKRI. Mewujudkan cita-cita luhur bangsa Indonesia agar dapat terwujud persatuan dan kesatuan. Fungsi mempertahankan persatuan dan kesatuan agar terwujud citacita luhur bangsa Indonesia, agara Indonesia lebih maju terutama dalam perbedaan agama dan suku dengan mamahami kepribadian mencintai perbedaan dengan cara saling menghargai antar sesama, saling menghormati menerima pendapat orang lain.

Pemahaman dan praktik kebhinekaan dengan penalaman perbedaan ras salah satu contoh saling menghormati pendapat orang lain , saling kenal mengenal tidak membeda-bedakan teman walaupun beda suku misalnya suku Papua. Perebdaan suku harus diperlaukan dengan baik dan adil sebagaimana disebutkan sila kelima dalam Pancasila , Keadilan sosial bagi seluruh rakyat Indonesia. (Wawancara dengan Ketua Keolahragaan, siswa Kelas XI).

Kebhinekaan adalah suatu keragaman berbeda suku, budaya, bahasa dan dialeg. Pengalaman berteman dengan lain suku didalam kelas saya banyak yang berasal dari luar daerah diantaranya dari Papua, Tana Toraja, Jawa, Bali dan Bugis Makassar tetapi kami tetap menemukan titik temu terhadap cara berfikir dan berbicara dengan mereka . Dengan demikian banyak pengalaman dan pelajaran baru didapatkan 
dari mereka dengan saling mengharagai memberikan mereka raung dan waktu untuk mengemukakan pendapat tanpa menyudutkan yang salah. Keragaman yang didapatkan dari guru, beberapa guru berasal dari suku yang berbeda dan cara berbicaranya agak sedikit keras namun kami faham bahwa guru tersebut tidak lain adalah untuk memberikan ilmu kepada siswa.

Kebhinekaan didapatkan dari literasi buku mata pelajaran PKN dan IPS di madrasah. Pemahaman kebhinekaan didapatkan dan sangat menarik karena dapat banyak memberikan pelajaran dan pengalaman dari teman-teman dari luar daerah. Tujuan kebhinekaan untuk saling mengenl perbedaan tanpa menyudutkan adat istiadat dan agama . Mewujudkan citacita luhur tentang keragaman, fungsinya agar terwujud persatuan dan kesatuan Bangsa terhadap beberapa perbedaan dalam mempertahankan kesatuan kesatuan persatuan dari berbagai macam budaya, agama sehingga menjadi satu kesatuan yang utuh walaupun berbeda tetapi tetap satu. Dan mencintai perbedaan saling menghargai , menghormati pendapat pemahaman dan mengedepankan keragaman.

Pengalaman dalam kebhinekaan antar suku, agama dan budaya saling bertukar cerita mengenai budaya dari teman-teman dari suku lain ketika berada di madrasah dengan memeperlakukan mereka semua dengan sikap yang sama. Implementasi keragaman yang dilaksanakan pada kehidupan sehari-hari di madrasah mulai dari berkomunikasi di kelas maupun di organisasi melalui lomba tarian antar budaya. (Wawancara dengan Wakil Ketua Relawan Anti Narkoba, siswa Kelas XI).

Kebersamaan dalam kehidupan di Madrasah dan masyarakat.kebersamaan tersebut dengan mengedepankan keragaman salah satunya nilai-nilai moderasi beragama mengakomodir budaya lokal yakni budaya di lingkungan madrasah pada komunitas di luar madrasah adalah Jawa Tondano dengan bahasa Hulondalo.
Kebersamaan yang diwujudkan dalam bentuk gotong royong dengan membantu menyiapkan konsumsi dan segala sesuatu yang akan disajikan pada hari raya ketupat.

\section{PENUTUP}

Madrasah yang terdiri dari beragam suku, etnis, budaya dan Mazhab dapat menerapkan Pendidikan moderasi beragama. Interaksi tersebut di bangun secara berkesinambungan agar terjalin kondisi yang kondusif di Madrasah. Praktik moderasi beragama dengan aspek toleransi dan akomodatif terhadap budaya lokal nampak nya telah terimplementasi, di karenakan siswa telah mengetahi dan memahami bahwa moderasi beragama toleransi dan akomodatif terhadap budaya lokal . Interaksi dengan siswa berjalan dengan baik dengan bmengedepankan nilai-nilai moderasi beragama .

Peserta didiknya terlihat memiliki wawasan tentang toleransi, dan akomodatif terhadap budaya lokal dengan menjalin komunikasi yang baik antara mazhab dan suku yang berbeda. Hal tersebut mereka serap dari proses pembelajaran agama termasuk kegiatan intrakurikuler dan pembelajaran ekstrakurikuler (kegiatan Rohis) dan muatan lokal pelajaran Kemuhammadiyahan pada kegiatan rohis pada Madrasah tersebut. Sepatutnyalah Kementerian Agama dalam hal ini seksi Madrasah dan Pendidikan Agama (Mapenda) agar mengapresiasi madrasah dengan memberikan fasilitas OSIS (organisasi siswa intra Madrasah) dalam hal buku literatur mengenai paham keagamaan agar siswa semakin mempunyai motivasiuntuk memahami dan mengimplementasikan nilai-nilai moderasi beragama, siswa mengambil pelajaran dari proses pembelajaran yang dilakukan oleh MAS Muhammadiyah Isimu ini agar kelak peserta didik mempunyai wawasan moderasi beragama, cinta perdamaian serta toleran dan akomodatif terhadap budaya lokal.

\section{UCAPAN TERIMA KASIH}


Ucapan terima kasih penulis ucapkan pada semua pihak yang terlibat baik informan maupun pihak yang lain, telah membantu terselenggaranya penilitian tersebut. Hal yang sama Ucapan Terima kasih kepada Balai Penelitian dan Pengembangan Agama Makassar yang telah memberikan motivasi kepada penulis .Kepada pimpinan redaksi jurnal Educandum dan jajarannya Mitra Bestari, teman-teman Tim Editor dan lembaga terkait yang telah membantu peneliti di lapangan penulis ucapkan terima kasih yang telah memuat tulisan ini.

\section{DAFTAR PUSTAKA}

Abdullah, Amin. 2005, Pendidikan Agama Era Multikultural Multireligius. Jakarta: PSAP

Anas, Sudijono, 2011. Pengantar Evaluasi Pendidikan, Jakarta: Rajawali Pers, 2011

Harahap, Syahrin. 2011. Teologi Kerukunan. Jakarta: Prebada Media.

Krathwohl, D.R. 2002. A Revision of Bloom's taxonomy. An overview: Theory into Practice, 41 (4)

L. Eck, Diana. 2006. What is pluralism?. http//pluralism.com. Diakses tanggal 5 April 2016

Langgulung, Hasan. 2003. Azas-azas Pendidikan Islam. Jakarta : Pustaka Al Husna; Cet-IV

Salim, Haitami. 2012. "Menggagas Pendidikan Agama Lintas Sekolah Berciri Khaskan Agama Yang Tidak Seagama". Dalam Jurnal -Analisis, Vol.12 No.2, Desember 2012.

Suardi, Moh. 2015. Ideologi Politik Pendidikan Kontemporer.

Yogyakarta : $\square$ e Publish.

Tim Peneliti Balai Litbang Agama Makassar. 2008. Optimalisasi Pelayanan Keagamaan Departemen Agama. Makassar : Balai Litbang Agama .

Walzer, Michael. 1997. On Toleration. New Haven and London: Yale University Press

\author{
Yusuf Anas, 2009. Managemen \\ Pembelajaran dan Instruksi \\ Pendidikan. Yogyakarta: Ircisod.
}

